\title{
The Stem Cells in Plants
}

\author{
Esin Oluk \\ Ege University, Faculty of Arts and Sciences, Department of Biology, Botany Division \\ 35100 Bornova-Izmir / Turkey \\ E-mail: esin.oluk@ege.edu.tr
}

\begin{abstract}
In this opinion article, studies done on definition of stem cells in several plant species, genetic control and the areas in which these cells are applicated in past decades have been criticized.
\end{abstract}

Key words: Stem cell, plant, pluripotency, shoot apical meristem, root apical meristem, cosmetics

DOI: $10.7176 / \mathrm{JSTR} / 6-02-01$

\section{Bitkilerde Kök Hücre}

\section{Özet}

Bu çalışmada, geçtiğimiz yakın dönem içerisinde çeşitli bitkilerle yapılan kök hücre varlığının tespitine yönelik çalışmalar, genetik kontrol, hayvan ve bitki kök hücrelerinin benzer ve farklı yönleri ile bitkisel kök hücrelerin kullanım alanları irdelenmeye çalışılmıştır.

Anahtar Kelimeler: Kök hücre, bitki, pluripotensi, sürgün apikal meristemi, kök apikal meristemi, kozmetik

\section{Giriș}

Biyolojik döngünün primer üreticileri olan bitkiler, apikal (uç) meristemlerindeki kurucu hücrelerden yeni dokular, organlar yapabilme yetenekleri ve yüzyıllara varan yaşam süreleriyle her zaman hayranlık uyandırmışlardır. Bu kurucu hücrelerin hayvanlardaki pluripotent kök hücrelere eşdeğer olup olmadığg bitki bilimciler arasında uzun süre tartışma konusu olmuştur. Günümüzde yapılan, özellikle genetik çalışmalar sonucu artık bitkilerin meristematik dokularının içinde özel kök hücre niteliğinde 6-9 hücreden oluşan bir hücre gurubu olduğu kabul edilmektedir (Stewart ve Dermen, 1970). Bu hücre tipleri, bölündüklerinde, oluşan yavruları kök hücre olarak kalabilen ya da farklılaşabilen klonojenik öncüller olarak tanımlanmaktadır (Laux, 2003). Son derece plastik ve versatil olan bu hücrelerin, yaralanan veya ölen dokuların yerini alabildikleri gibi, bitkide tipik bir savunma mekanizması oluşturduklarından da bahsedilmektedir (Nisa vd., 2019). Tüm bu özellikleri nedeniyle bitkisel kök hücreler son yıllarda kozmetik dünyasında da kullanılmaya başlanmıştır. Bitkisel kök hücrelerde, mevcut bitkisel ekstraktlarda kullanılan ana bileşenin -özellikle ekstraksiyon yöntemlerinden kaynaklanan herhangi bir şekilde- kaybı ya da hasarı olasılığının ortadan kalktığı belirtilmektedir. Bu nedenle, günümüzde, bitkisel kök hücrelerin in vitro şartlarda cilt kırışıklıklarını azaltıcı ve hatta insan kök hücrelerinin çoğalmasını \% 80 oranında arttırıcı yönündeki gelişmeler geniş yankı uyandırmaktadır (Sengupta vd., 2018). Bu çalışmada, meristemlerden hareketle bitkisel kök hücre kavramı, genetik kontrolü, hayvansal kök hücrelerle benzeyen ve ayrışan yönleri ile günümüzdeki kullanım alanları irdelenmeye çalışılmıştır.

\section{Bitkisel Meristemler}

Bitkilerde (tohumlu) gerek embriyogenez (embriyonik safha), gerek tohum çimlenmesi esnasında (postembriyonik safha) ve ilaveten çok yıllık bitkilerde ömürleri boyunca yeni doku ve organları veren; böylece büyümeyi sağlayan bölünür hücre bölgeleri mevcuttur. Bu bölgelere "meristem" adı verilir. Meristemler yer aldıkları bölgelere ve niteliklerine göre sinıflandırılabilirler (Machida vd., 2013)(tablo $1,2)$. 
Tablo 1- Meristemlerin bulunuş yerleri ve niteliklerine göre sınıflandırılmaları

\begin{tabular}{|l|l|lc|}
\hline \multirow{2}{*}{ Bulunduğu bölge } & \multirow{2}{*}{ Niteliği } & \multicolumn{2}{c|}{ Bitki Tipi } \\
\cline { 3 - 4 } & & Otsu & Odunsu \\
\hline Kök Ucu & PM & + & + \\
\hline Sürgün Ucu & PM & + & + \\
\hline Nodyumun altı (interkalar) & PM & + & + \\
\hline Kök enine kesit (perisikl) & PM & + & + \\
\hline Kök enine kesit (kambiyal) & SM & + & + \\
\hline Gövde enine kesit (kambiyal) & SM & & + \\
\hline Kök ve gövdede epidermisin altı (fellojen) & SM & + & \\
& & & \\
\hline
\end{tabular}

PM: Primer meristem, SM: Sekonder meristem

Tablo 2- Primer ve sekonder meristemlerin hücresel özellikleri ve işlevleri

\begin{tabular}{|l|l|}
\hline \multicolumn{1}{|c|}{ Primer Meristem } & \multicolumn{1}{c|}{ Sekonder Meristem } \\
\hline $\begin{array}{l}\text { Hücreleri zengin protoplastlı, iri } \\
\text { nukleuslu ve az (ya da hiç) vakuollü } \\
\text { olup şekil olarak izodiyametriktir }\end{array}$ & $\begin{array}{l}\text { Hücreler uzun, dikdörtgen şeklinde olup } \\
\text { bol vakuollüdür }\end{array}$ \\
\hline $\begin{array}{l}\text { Lonjitudinal yönde büyümeye sebep } \\
\text { olurlar (uzama) }\end{array}$ & Işınsal yönde büyümeye sebep olurlar \\
\hline $\begin{array}{l}\text { Primer dokuları (primer floem, } \\
\text { epidermis vb.) vererek primer büyümeyi } \\
\text { sağlarlar }\end{array}$ & $\begin{array}{l}\text { Sekonder dokuları (sekonder floem, } \\
\text { fellem vb.) verirler ve sekonder } \\
\text { büyümeyi sağlarlar }\end{array}$ \\
\hline $\begin{array}{l}\text { Bitki büyümeye başladığında ortaya } \\
\text { çkarlar }\end{array}$ & Primer büyümeden sonra oluşurlar \\
\hline
\end{tabular}

(https://www.easybiologyclass.com/difference-between-primary-and-secondary-meristem/'den düzenlenmiştir).

Sekonder meristemler erişkin bir dokudan kökenlenirken, primer meristemlerin kökenini oluşturan hücrelerin ne olduğu uzun süre araştırma konusu olmuştur. Bu süreçte farklı bilim insanları sürgün ucundaki köken hücre için "promeristem" (Clowes, 1961), "kurucu hücre" (Newman, 1965), "inisiyal” (Esau, 1965) ya da "metrameristem" (Tolbert ve Johnson, 1966) gibi farklı terimler kullanmışlardır. Kök ucunda bu konuyla yapılan araştırmalar ise nispeten yenidir ve sonuç olarak "durgunluk merkezi” adı verilen ve meristem hücrelerinin hemen altında yer alan bir hücre kümesi, buradaki primer meristematik hücrelerin kaynağı olarak gösterilmiştir (Sachs, 2005).

Son yıllarda, hayvan (özellikle memeli) terminolojisinde yaklaşık altmış yıl önce ortaya çıkan (Richards, 1955) ve kabul gören "kök hücre (pluripotent)" kavramının, bitki sürgün ucundaki "kurucu hücrelere" ve kök ucundaki "durgunluk merkezinin çevresinde bulunan hücrelere" uygulanıp uygulanamayacağ1 tartışılmaya başlanmıştır.

\section{Bitkilerde kök hücre ve niş kavramı}

Kök hücrelerin günümüzdeki tanımı "bölündüklerinde yavruları kök hücre olarak kalabilen, ya/ ya da farklılaşma sürecine giren klonojenik öncüller” olarak yapılmaktadır (Laux, 2003). Bu hücrelerin özelleşmiş (ergin) dokulara farklılaşma ya da yaralanan dokulardaki hücrelerin yerine yenisini oluşturma gibi işlevleri vardır. Özellikle, olumsuz çevresel koşullara daha fazla maruz kaldıkları kök ve sürgün ucunda bulunan kök hücrelerin, oluşan DNA hasarını bir uyarı kabul ederek kendi kendilerini öldürüp, bitkinin geri kalanını kurtarmak şeklinde hareket ettikleri de bulunmuştur (Nisa vd., 2019). Bu nedenle sürekli bölünürler ve böylece kendilerini yenilerler.

Bir hücrenin kök hücre olup olmadığını anlamak için klonojenik (hücre klonu oluşturma) özellik taşıyıp taşımadığının belirlenmesi gerekir. Bu amaçla çeşitli moleküler biyolojik işaretleme teknikleri geliştirilmiştir. Bir hücre genetik olarak işaretlendiğinde bu işaretli hücreden çoğalan yavru hücrelerin bu genetik işareti taşıyıp taşımadığına bakılır (Stewart ve Dermen, 1970; Heidstra vd., 2004). Bir gurup araştırmacı, model bitki Arabidopsis'in köklerinde ilgili hücre hatlarını işaretlemek için muhbir gen 
(kolayca tanınabilir bir ürün kodlayan yapay gen) kullanmışlardır (Dolan ve ark., 1994; Scheres ve ark., 1994; Kidner ve ark., 2000). Bu çalışmanın işleyişinde, öncelikle hücrelerdeki muhbir gen bir transpozon (genom çevresinde hareket edebilen DNA parçası) tarafından bloklanır. Sonra hücreler, transpozon kök meristemindeki sadece birkaç hücrede muhbir genin çalışmasındaki bloğu kaldıracak şekilde hareket ettiğinde, işaretlenmiş olur. Nihayetinde, artık bu hücrelerde ve akrabalarında muhbir gen çalışmaya başlar. "Klonal analiz (klon hücre ya da hücre klonu=aynı atadan kökenlenen genetik olarak özdeş hücre guruplarının analizi)" adı verilen bu yöntemle, bir bitkinin büyümesi için gerekli tüm doku ve organların işaretlenen tek bir "kurucu" hücreden türevlendiği ortaya konmuştur (Furner and Pumfrey, 1992; Irish and Sussex, 1992; Schnittger vd., 1996). Bu sonuçlar da bilim adamlarına bitkilerin uç meristemlerinde bulunan kurucu hücrelere "kök hücre" nitelemesi yapma hakkı doğurmuştur (şekil 1,2).

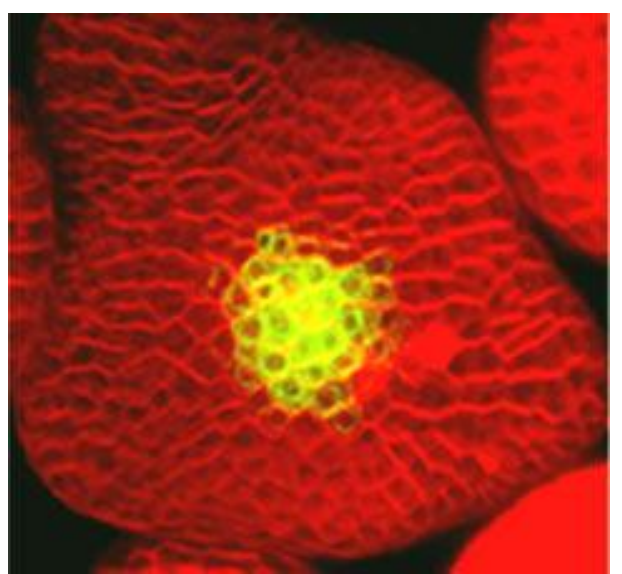

Şekil 1- Arabidopsis sürgün ucunda kök hücreler (sarı). [TCS-NT confocal laser scanning microscope (Leica, Heidelberg, Germany]. (https://www.nature.com/stemcells/2009/0903/090312/full/stemcells.2009.39.html).

Şekil 2- Arabidopsis kök ucunda kök hücreler (turuncu) [TCS-NT confocal laser scanning microscope (Leica, Heidelberg, Germany]. (www.sciencedaily.com/releases/2009/11/091116165633.htm).

Kök hücreler sürgün ucu meristeminde merkezi zonun apikal tabakalarında 6-9 hücrelik bir populasyon oluşturur (Satina vd., 1940; Stewart ve Dermen, 1970; Große-Hardt ve Laux, 2003) (şekil 3). 


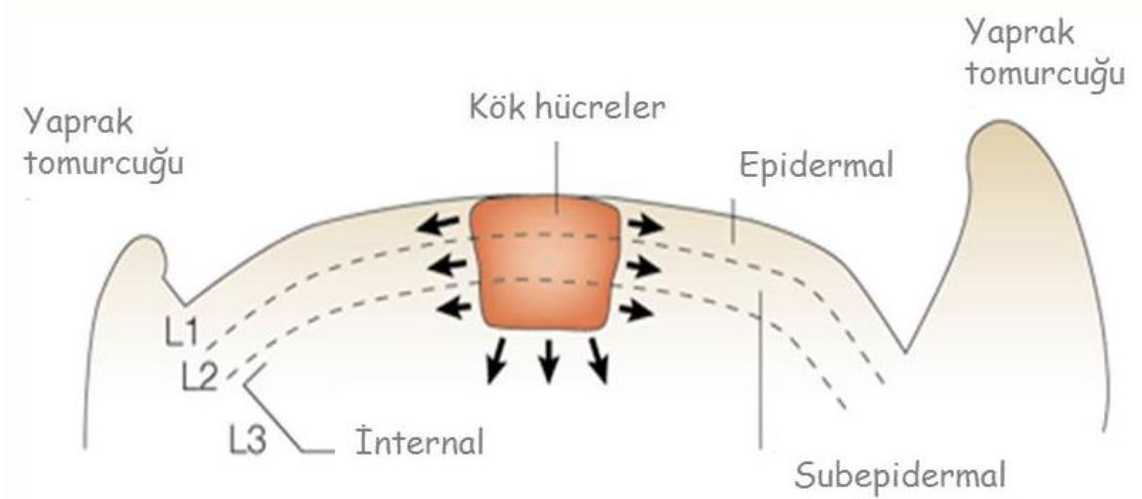

Şekil 3- Sürgün ucu meristeminin tabakasal düzenlenişinde kök hücrelerin yerleşimi. L1: Epidermal tabaka, L2: Subepidermal tabaka, L3: Internal tabaka (https://slideplayer.com/slide/9414039/'dan düzenlenmiștir).

Populasyon büyüdükçe merkezdeki hücreler kök hücre halinde kalmaya devam ederken, merkezden uzaklaşanlar periferal zona doğru kayarak farklılaşma sürecine girer (şekil 4) (Ball, 1960; Stewart ve Dermen, 1970; Große-Hardt ve Laux, 2003).

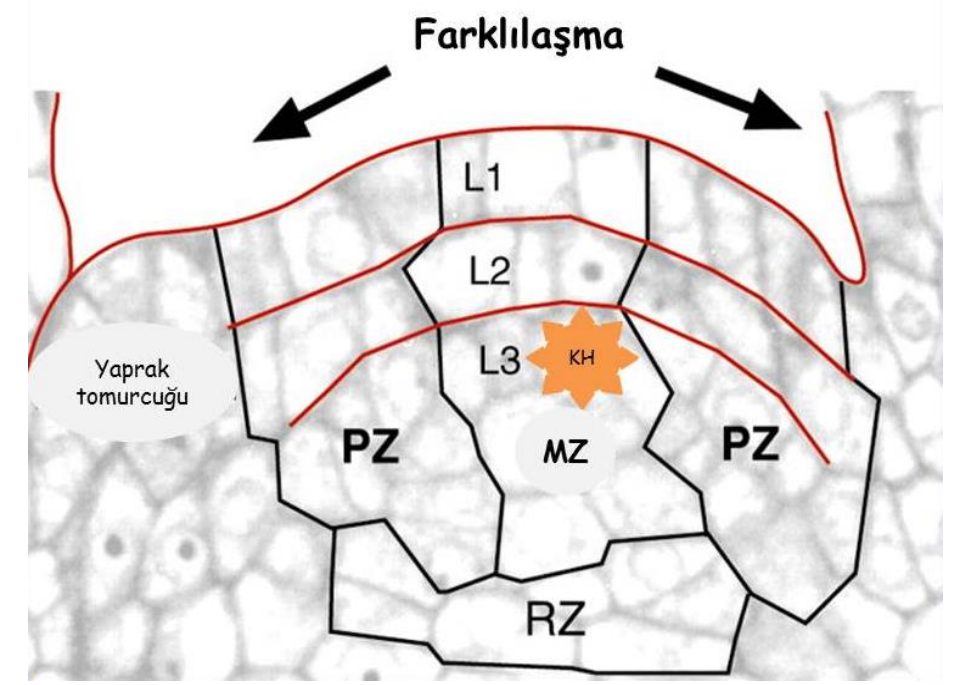

Şekil 4- Sürgün ucu meristeminin geometrik düzenlenişinde kök hücreler $(\mathrm{KH})$ ve farklılaşma süreci. MZ: Merkezi zon, PZ: Periferal zon, RZ: Rib (öz) zonu (Große-Hardt ve Laux, 2003'ten düzenlenmiştir).

$\mathrm{Bu}$ durumun, yani kök hücre halinde kalma ile farklılaşmaya yönelmenin, hangi faktörlerle kontrol edildiği uzun süre merak konusu olmuştur. 2000li yılların başında yapılan çalışmalarla kök hücre kimliğinin merkezi zonun hemen altında yer alan "organizasyon merkezi” adı verilen özel bölgedeki hücrelerden salınan sinyallerle düzenlendiği anlaşılmıştır (Mayer vd.,1998; Spradling vd., 2001). Moleküler biyolojik çalışmaların ortaya koyduğuna göre, kök hücre halinde kalınmasını sağlayan sinyal molekülü, organizasyon merkezi hücrelerinde bulunan Wuschel (WUS) genidir (Mayer vd.,1998; Schoof vd., 2000). Bu gen kök hücrelerde aynı zamanda Clavata 3 (CLV3) genini -WUS'un sinyal ligandı olarak etkinlik gösteren- uyarır. İki gen arasındaki bu negatif geri besleme sayesinde bitkinin kök hücre popülasyonu büyüklüğünü dinamik olarak kontrol eden oto-düzenleyici bir sistem meydana gelir (Brand vd., 2000; Schoof vd., 2000) (şekil 5). 


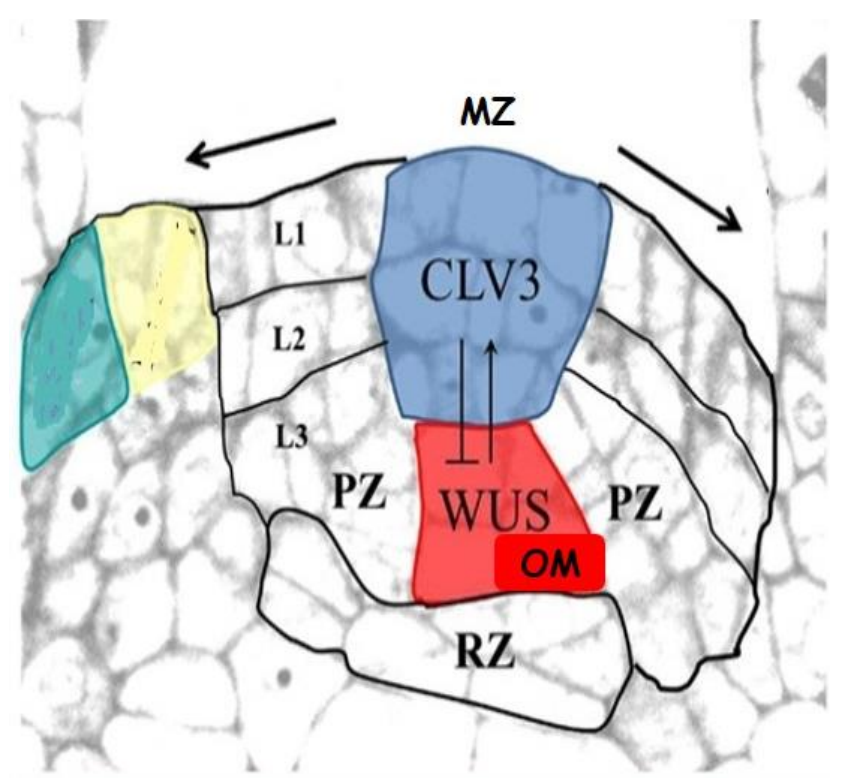

Şekil 5- Merkezi zon (CLV3 kaynağı) ve organizasyon merkezi (WUS kaynağı) arasında meydana gelen genetik negatif geri-besleme. MZ: Merkezi zon, PZ: Periferal zon, RZ: Rib (Öz) zonu, OM: Organizasyon merkezi (Mavi-Sarı bölge yaprak tomurcuğunu işaret etmekte, kalın oklar farklılaşma yönünü göstermektedir. Bosca San Jose vd., 2011'den düzenlenmiştir).

Kök hücrelerin sürekli yeni dokular oluşturma süreci, içinde yer aldığı organizmanın ihtiyaçlarına göre düzenlenir. Kök hücre halindeki hücre miktarı ile farklılaşan hücre sayısı arasındaki bu denge kök hücre aleyhine bozulursa (yeterince sık bölünemezlerse) dokular büyüyemez ya da eski dokuların yerini yenileri alamaz; farklılaşan hücre aleyhine bozulduğunda ise (yani kök hücreler kontrolsüzce çoğalırsa) kısırlık veya düşük fertilite, anormal gövde, adventif sürgün oluşumu, birleşik infloresens-gövde oluşumu, cücelik gibi gelişim anormalileri meydana gelebilir (Orford \& Scadden 2008; He, Nakada, \& Morrison 2009; Lee ve Clark, 2015) (şekil 6).

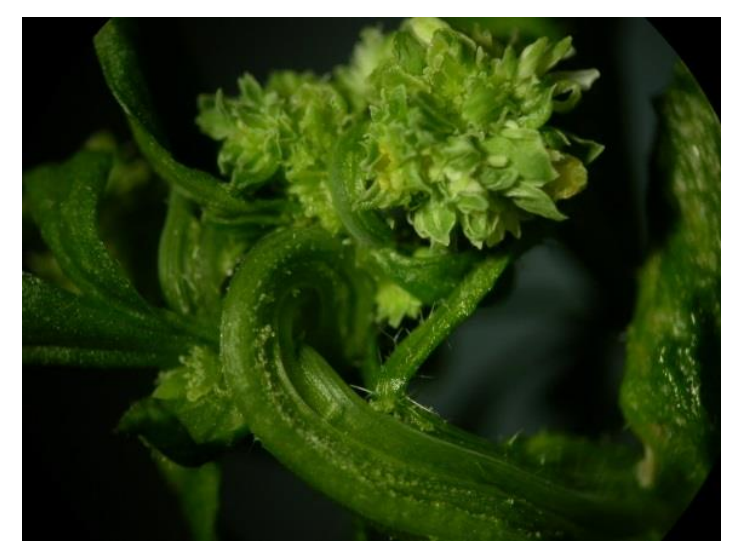

Şekil 6- WUS geni eksikliğinde tepe tomurcuğunda meydana gelen dejenerasyon. (http://www.cres-t.org/cgi-

bin2/phenotype_search2.cgi?PH=104\&indivisual=on\&bulk=on\&sort=phenotype)

Bitkinin diğer ucunda kök meristemi de sürgün meristemine benzer bir organizasyona sahiptir. Burada kök hücreler, fonksiyonu sürgün meristemindeki OM'ne benzeyen, kendilerini farklılaşmaktan alıkoyan ve "durgunluk merkezi (DM)" adı verilen küçük bir gurup hücrenin etrafını kuşatır (Van Der Berg ve ark., 1997) (şekil 7). 


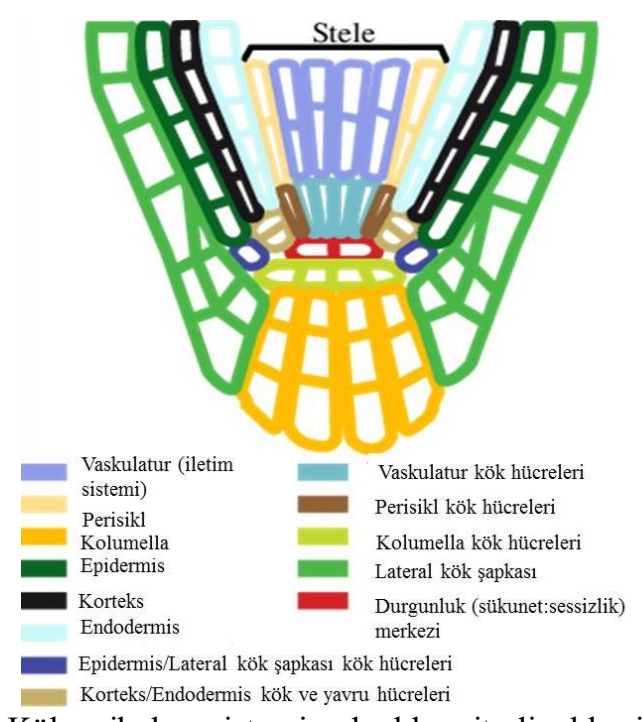

Şekil 7- Kök apikal meristemi radyal longitudinal kesit diyagramı.

(https://www.researchgate.net/figure/Diagram-of-a-radial-longitudinal-section-through-root-apicalmeristem-RAM-showing-the fig3 47556606'dan düzenlenmiștir).

Kökteki durgunluk merkezinden salınan sinyal molekülü WUS'la aynı gen ailesinden olan WOX5 geni (Kamiya vd., 2003; Haecker vd., 2004), durgunluk merkezinin etrafinda yer alan kök hücrelerde bulunan ve WOX5'i baskılayan gen ise yine CLV ile aynı gen ailesinden olan CLE40 (Hobe vd., 2003) genidir. Kök ucu meristeminin bir diğer farkı da, burada kök hücrelerinin "kendini yenileyebilirliği" hücre populasyonu şeklinde değil tek hücre seviyesinde gerçekleşmesidir. Her bir kök hücrenin bölünmesi asimetrik yavru hücre meydana getirir. Yavru hücrelerden biri DM'yle bağlantı halinde kalarak kök hücre halini korumaya devam ederken, diğer yavru hücre DM'den ayrılır ve farklılaşma sürecine girer (Laux, 2003).

Bitkilerin kök kısmındaki kök hücrelerin kök hücre halinde kalabilmesinin komşu hücrelerden (DM) gelen sinyallerle sağlandığı "seçili hücre öldürülmesi" yöntemiyle gösterilmiştir (Van der Berg ve ark., 1997). Araştırmacılar kök ucu meristeminde, kök hücrelerin kuşattığ 1 özgün birtakım hücreyi (DM) lazer 1şınıyla öldürdüklerinde komşu kök hücrelerin farklılaşmaya başladıklarını saptamışlardır. Bu durum, basitçe, lazerle yaralanmanın bir sonucu olarak değerlendirilemez, çünkü DM'den başka, diğer komşu hücreleri öldürmek farklılaşmayı teşvik etmemiştir. Bu sonuçlar sayesinde, kökteki DM'nin kök hücreleri farklılaşmaktan alıkoyan (diğer bir deyişle, kök hücre halinde kalmalarını sağlayan) sinyalin kaynağı olduğu netleşmiştir.

Gerek sürgün ucunda (OM) gerekse kök ucunda (DM) kök hücrelerin akıbetini belirleyen bu bölgeler: Newman'ın 1965'te “inisiyaller (günümüzde kök hücreler) kalıcı bir ofisin geçici misafirleridir” önerisi ve Schofield'in bu öneriden hareketle hayvansal kök hücreler için oluşturduğu niş konsepti referans alınarak (Schofield, 1978) "kök hücre nişi”" olarak adlandırılmıştır (şekil 8).

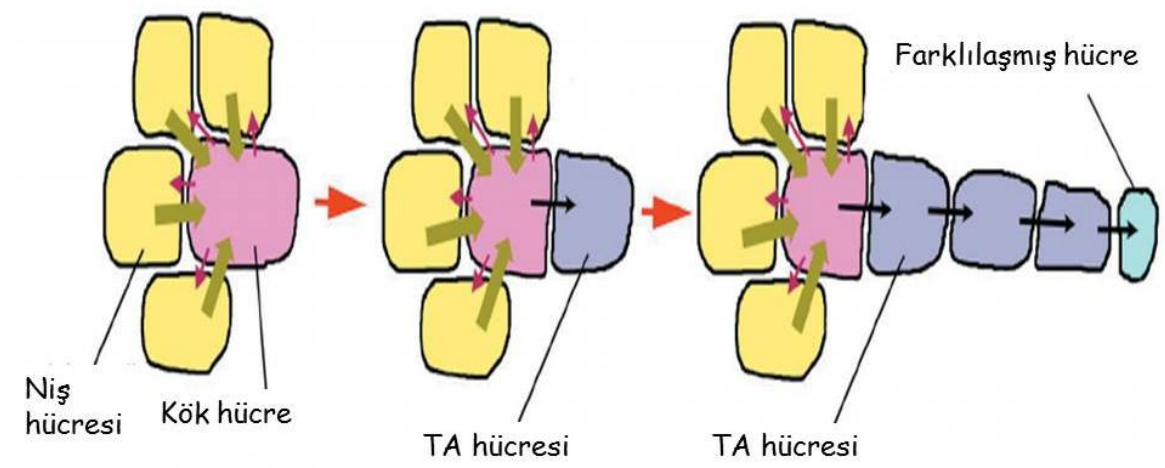

Şekil 8- Bir kök hücre bölünmesi kök hücre ve çevresindeki niş hücreleri arasındaki sinyal değişimi yoluyla kontrol edilir. Yavru kök hücreler farklılaşmadan önce bir transit amplifiye (TA) hücre olarak birkaç tur hücre bölünmesi geçirirler. Kök hücre teşvik edici sinyal (WUS) sarı renkli, geri besleme sinyalleri (CLV) kırmızı renkli okla gösterilmiştir (Stahl ve Simon, 2005 'ten düzenlenmiştir). 
Diğer bir deyişle, bitkilerde gerek sürgün ucunda gerekse kök ucundaki kök hücreler, kök hücre halinde kalabilmelerini sağlayan sinyallerin salındığı küçük bir çevre (mikroçevre) içinde bulunurlar. İşte bu küçük çevreye "kök hücre nişi” adı verilmektedir.

\section{Bitki ve hayvan kök hücreleri arasındaki benzerlikler-farklılıklar}

Schofield, hematopoietik (hayvansal) kök hücreler için niş konseptini ortaya koyduktan sonra hayvan kök hücrelerinin de, bitkilerde olduğu gibi, kök hücre durumunda kalabilmek için kendilerini çevreleyen hücrelerden sinyal almaya ihtiyaç duydukları anlaşılmıştır (Spradling ve ark., 2001). Diğer bir deyişle, her iki alemde de kök hücrelerden kökenlenen hücrelerin gelişim kapasitesi kök hücre tarafindan değil, oluşan yavru hücrenin içinde bulunduğu çevre tarafindan belirlenir (Morrison, 2001). Yine bitkilere benzer şekilde hayvan kök hücre havuzu da hem hücre populasyonu hem de tek hücre seviyesinde düzenlenebilir. Buradan, kök hücre halinin gerek bitkilerde gerekse hayvanlarda pozisyonel bilgiyle korunduğu ortaya çıkmaktadır (Laux, 2003).

Sonuç olarak bitkiler ve hayvanlar farklı tekil atalardan gelişmiş olsa da,

a) hücre setlerini -özgün bölgelerde ve günlük hasar gören hücreler için bir depo oluşturmak üzerenispeten farklılaşmamış durumda tutmak için

b) ya da bölünemeyen özelleşmiş hücre (farklılaşmış) yapımına duyulan ihtiyaçla büyümeye duyulan ihtiyaç arasındaki dengeyi sağlamak için

birbirlerinden bağımsız ama benzer şekilde "kök hücre oluşturma" stratejisini geliştirdikleri söylenebilir (Meyerowitz, 2002; Sablowski, 2010).

Benzerlik kök hücrelerin gelişimsel rollerinde, dokulardaki düzenlenişlerinde ve davranışlarını kontrol eden moleküler mekanizmalarda da devam etmektedir. Yine hem bitkilerde ve hem de hayvanlarda kök hücre nişleri, kök hücrelerin lokasyon ve proliferasyon oranlarını tüm organizmanın ihtiyaçlarına uyduran benzer araçlar olarak gelişmişlerdir. Öte yandan, bitki ve hayvanlarda (evrimsel süreçte) korunmuş olan ve bir hücrenin bölünmeye devam $\mathrm{m}$ edeceği yoksa farklılaşmaya mı yöneleceği hakkında karar vermede merkezi rol oynayan ortak bir genden de söz edilmektedir. Bu gen Retinoblasoma $(\mathrm{Rb})$ proteinini kodlamaktadır (Sablowski, 2010). Rb proteini etkinleştiğinde, daha az karakterize edilmiş hücre farklılaşmasını sağlayan işlevlerine ilaveten, DNA'yı replike eden genleri baskılamaktadır (Burkhart \& Sage 2008). Arabidopsis'le yapılan çalışmalarda, bu proteini kodlayan gen kök meristeminde etkisizleştirildiğinde kök hücrelerin akrabalarının farklılaşamadığı görülmüştür. Tersine, bu gen yapay olarak etkinleştirildiğinde ise ilgili hücrelerin bölünmeyi durdurup farklılaşmaya başladıkları saptanmıştır (Wildwater ve ark., 2005). Benzer şekilde hayvanlarda da aynı proteinin kök hücrelerin farklılaşmaya yönelmesini teşvik ettiği anlaşılmıştır (He, Nakada ve Morrison, 2009). Bu tür benzerliklerin tek hücrelilerde zaten var olan ve hücre bölünmesi ve farklılaşmasını kontrol etmek üzere geliştirilen mekanizmalardan kökenlendiği söylenmektedir (Sablowski, 2004; Scheres, 2007).

Kök hücrelerin pluripotensi özelliği ise kromatinin düzenlendiği yola, yani, DNA'nın nukleusta paketlenişine ve bu paketlenişin hücre farklılaşması için gerekli genleri düzenleyici proteinlerin bağlanmasını etkileyişine, bağlı bulunmaktadır. Burada "polikomb proteinleri” farklılaşma genlerini baskılamak üzere kromatini düzenlemede ve böylece hayvan kök hücrelerinin pluripotensi özelliğini korumada önemli rol oynamaktadırlar (He, Nakada ve Morrison, 2009). Aynı proteinlerin bitkilerde de pluripotent ve farklılaşma safhaları arasındaki geçişi düzenlediği görülmüştür. Ancak, hayvanlardakinden farklı olarak, normalde meristemde çalışan genleri baskılayabilmeleri için farklılaşan hücrelerde olmaları gerektiği anlaşılmıştır. Bu durum, mutasyona uğramış polikomb genlerine sahip Arabidopsis bitkisiyle gösterilmiştir. Bu bitkilerde sürgün meristemi genleri yaprakları meydana getirecek hücrelerde çalışmaya devam ederler ve sonuçta yapraklarda anormali meydana gelir (Katzal ve ark., 2004; Schubert ve ark., 2006).

Özetle, Rb proteini hem bitkilerde hem hayvanlarda kök hücre nişini terk eden hücrelerde bölünmeyi durdurma ve farklılaşmayı başlatma yönünde benzer şekilde iş görmektedir. Polikomb proteinleri ise her iki krallıkta da suskun kromatin safhasının korunmasını sağlamakta ortak işleve sahipken, kök hücrelerde farklı şekilde iş görmektedir; hayvanlarda "kök hücrelerde" farklılaşma genlerini baskılayıp, bitkilerde "farklılaşmış hücrelerde" meristematik genleri engellemektedirler. Bu bilgilerden hareketle, harekete geçiş yollarında birtakım farklılıklar olma olasılığına rağmen hayvanlarda kök hücre halini kontrol eden genlerin en azından bazılarının bitki kök hücreleriyle ilgisi olduğu söylenebilir.

Aralarındaki bu benzerliklere karşılık bitki ve hayvan kök hücreleri arasında farklılıklar da mevcuttur. Mesela hayvansal kök hücre nişlerinde kullanılan sinyal moleküllerinin, embriyogenez sirasında büyümenin organize edilmesi ve doku örneklemesi süreçlerinde kullanılan ve Drosophiladan elde edilen Notch, Wingless ve Hedgehog proteinlerinin homologları gibi moleküller olduğu belirtilmektedir (Orford \& Scadden 2008; He, Nakada, \& Morrison 2009). Ayrıca, bitki kök hücreleri gerek embriyonik gerekse post-embriyonik safhada totipotent özelliklerini korurken hayvansal akranları bu özelliklerini

7 I P a g e

www.iiste.org 
embriyogenezin blastula safhasından sonra kaybederler. Buna karşılık, yapılan son çalışmalar kök hücrelerin gelişimsel kapasitesinin (potensi) kalıtsal bir özellik olmayıp oluşan yavru hücrelerin içinde bulunduğu ortam (niş) tarafindan yönlendirildiğini göstermektedir (Steeves ve Sussex, 1989; Blau vd., 2001; Morrison, 2001; Sablowski, 2010).

Bitki ve hayvan hücreleri arasındaki bir diğer önemli fark da bitkilerin farklılaşmış parçalarından kök hücrelerin de novo oluşabilmesi kolaylığıdır. Mesela, ana kökün farklılaşmış periskl hücrelerinden yanal kök meristemlerinin oluşumu buna tipik bir örnektir. Yani, önceden farklılaşmış bir hücre farklılaşmasını yitirir ve çoklu hücre akıbetini meydana getirir (Malamy ve Benfey, 1997). Doku kültürü ve transgenik bitkilerle bu yetenek nispeten basit manipulasyonlarla çoğu doku için gösterilmiştir. Ve bu gözlemler, hepsi için değilse de, çoğu farklılaşmış bitkisel hücre tipi için “totipotensi kavramı"na öncülük etmiştir (Steves ve Sussex, 1989). Ancak bu gözlemler aynı zamanda şu soruyu da gündeme getirmiştir. Eğer bitkilerde her hücre kök hücre özelliğine sahipse "kök hücre konseptini”" oluşturmanın bir faydası var midır?

Yukarıda verilen kök hücre tanımından hareketle normal bir bitkide kök hücre fonksiyonunun sadece meristemlerle sınırlı olduğu söylenebilir. Ayrıca, sürgün meristemi için operasyonel bir kök hücre belirteci olan CLV3, farklılaşmış hücrelerde çalışmamaktadır; de novo meristem oluşumu sırasında tekrardan aktive edilmelidir. Tüm bunlardan şu yargıya varılabilir, bitki hücreleri kök hücre özelliklerini korumazlar, aktif şekilde tekrar kök hücre haline girmeleri gerekir. Bitkilerin tersine, farklılaşmış hayvan hücreleri bulundukları konumda (kök hücre veya farklılaşmış hücre konumunda) daha sıkı şekilde tutulmaktadırlar; bu bloğu aşabilmek için henüz bir strateji geliştirilememiştir. Bu nedenle, bitki ve hayvanların farklı rejeneratif potansiyellerinin kök hücrelere değil de bu hücrelerin farklılaşmış akrabalarının bir kök hücre haline dönüşebilme kolaylığına bağlı olduğu belirtilmektedir (Laux, 2003).

\section{Kök hücrelerin kullanım alanları}

Günümüzde tıptaki kullanımları ve hayvansal embriyonik kök hücre kullanışının ne derece etik olduğuyla ilgili tartışmalarla sık sık gündeme gelen kök hücreler, biyologlar açısından bitkiler de dahil olmak üzere tüm karmaşık canlıların gelişim süreçlerindeki “merkezi oyuncular” olarak değerlendirilmektedir. Bu yönüyle, hayvan kök hücrelerinin klinik olarak çeşitli kanser (Lin vd., 2019) ya da felç (Eggenberger vd., 2019) hastalıklarının tedavilerinde kullanılmakta olduğu bilinmekle birlikte, bitki kök hücrelerinin uygulama çalışmaları henüz yeni yeni ortaya çıkmakta ve öncelikli alanın kozmetik olduğu göze çarpmaktadır (Trehan vd., 2017; Sengupta vd., 2018). Kozmetikte bitki kök hücre praparatları iki şekilde hazırlanmaktadır. İlkinde, kök hücrede var olan hedef metabolit (etken madde) izole edilerek, ikinci yöntemde ise hedef metabolite sahip olan kök hücre tümüyle preparat haline getirilmektedir (tüm kök hücre preparatları (TKH)) (Schmidt vd., 2008; Toso ve Melandri, 2011; Morus vd., 2014). TKH preparatlarında herhangi bir şekilde ekstraksiyon yöntemi kullanılmadığı için hedef metabolitin (etken maddenin) hasarı ya da kaybı söz konusu değildir. Bu nedenle bu preparatların klasik bitkisel preparatlara göre daha etkili olduğu belirtilmektedir. Söz konusu preparatların özellikle cilt ve saç rejenerasyonunu teşvik ettiği, cilt yaşlanma belirtilerini geciktirdiği ve aynı zamanda belli bir genetik profile sahip olup bu genetik faktörlerin insan kök hücreleri üzerinde de etkili olduğu vurgulanmaktadır. (http://www.vytrus.com/). Yapılan denemelerde, ekstraktın \% 0.1'lik derişiminin in vitro şartlarda inkübe edilen insan kordon kanı kök hücrelerinin proliferasyonunda \% 80'lik bir artış meydana getirdiği ileri sürülmektedir

(https://www.ncbi.nlm.nih.gov/pmc/articles/PMC5674215/pdf/fsoa-03-226.pdf). Öte yandan ekstraktın kaz ayağı tabir edilen göz çevresindeki kırışık bölgeye uygulanmasıyla 2-4 hafta sonunda kırışıklıklarda sırasıyla \% 8-15 arasında azalma meydana geldiği verilen sonuçlar arasındadır (www.ctkcosmetics.com). $\mathrm{Bu}$ sonuçlar akıllara gelecekte bitki kök hücrelerinin, etik tartışmalara neden olan hayvansal kök hücrelerinin kullanımının yerini alabileceği düşüncesini getirebilir. Ancak, firma ar-geleri’nin bu özel ektraktlarda kalluslardan indirgedikleri süspense hücreleri (hücre süspansiyon kültürü) kullandıklarını belirtmeleri soru işareti doğurmaktadır. Kallusu oluşturan hücreler için tam olarak kök hücrelerdir denip denemeyeceği tartışmaya açıktır. Kallus hücreleri bir kök hücreden kökenlenmezler; onlar daha önce farklılaşmış bir hücrenin farklılaşma yeteneğini kaybetmiş akrabalarıdır. Son dönemde, Sang vd.'nin (2018) ortaya koyduğuna göre ise bitki kök hücrelerinin artan çalışmalarla giderek aydınlatılması hücresel programlama, hücre akıbeti ve kök hücre özgünleşme mekanizmalarıyla ilgili soruların cevaplanmasına yardım etmesinin yanı sıra- tarımda ve biyoteknolojideki uygulamalarında büyük rol oynayacaktır. Biyoteknolojik alanda rekalsitrant türlerin genetik transformasyonu ve çoğaltımıyla ilgili bir çalışmanın (Lowe vd., 2016) halihazırda gerçekleştirildiği yine aynı araştırmacılar (Sang vd., 2018) tarafindan işaret edilmiştir. 


\section{Kaynakça}

Ball, E. (1960). Cell divisions in living shoot apices. Phytomorphology, 10,377-396.

Blau, H., Brazelton, T.R. \& Weimann, J. (2001). The Evolving Concept of a Stem Cell. Cell, 105, 829-41.

Brand, U. et al. (2000). Dependence of stem cell fate in Arabidopsis on a feedback loop regulated by CLV3 activity. Science, 289, 617-619.

Bosca San Jose, S., Knauer S \& Laux T. (2011). Embryonic Development in Arabidopsis thaliana: From the Zygote Division to the Shoot Meristem. Frontiers in Plant Science, 2.93.

Burkhart, D.L. \& Sage, J. (2008). Cellular metabolisms of tumour suppression by the retinoblastoma gene. Nature Reviews Cance, . 8, 671-682.

Clowes FAL. (1961). Apical Meristems. Blackwell Scientific Publications, Oxford, England, 216 p.

Dolan, L. et al. (1994). Clonal relationships and cell patterning in the root epidermis of Arabidopsis. Development, 120, 2465.

Eggenberger, S. et al. (2019). Stem cell treatment and cerebral palsy: Systemic review and metaanalysis. World J Stem Cells, 26; 11(10), 891-903.

Esau, K. (1965). Plant Anatomy. John Wiley and Sons, New York, 767 p.

Furner, I.J. \& Pumfrey, J.E. (1992). Cell fate in the shoot apical meristem of Arabidopsis thaliana. Development, 115, 755-764.

Groß-Hardt, R. \& Laux, T. (2003). Stem cell regulation in the shoot meristem. Journal of Cell Science, 116, 1659-1666.

Haecker, A. et al. (2004). Expression dynamics of WOX genes mark cell fate decisions during early embryonic patterning in Arabidopsis thaliana. Development, 131, 657-668.

He, S., Nakada, D., Morrison, S.J. (2009). Mechanisms of stem cell self-renewal. Annu Rev Cell Dev Biol, 25,377-406.

Heidstra, R., Welch, D. \& Scheres, B. (2004). Mosaic analyses using marked activation and deletion clones dissect Arabidopsis SCARECROW action in asymmetric cell division. Genes Dev, 18(16), 1964-1969.

Hobe, M. et al. (2003). Loss of CLE40, a protein functionally equivalent to the stem cell restricting signal CLV3, enhances root waving in Arabidopsis. Development Genes and Evolution, 213, 371 381.

Irish, V.F. \& Sussex, I.M. (1992). A fate map of the Arabidopsis embryonic shoot apical meristem. Development, $115,745-753$.

Kamiya, N. et al. (2003). Isolation and characterization of a rice WUSCHEL-type homeobox gene that is specifically expressed in the central cells of a quiescent center in the root apical meristem. Plant J, 35, 429-441.

Katz, A. et al. (2004). FIE and CURLY LEAF polycomb proteins interact in the regulation of homeobox gene expression during sporophyte development. Plant J, 37(5),707-719. 
Kidner, C. et al. (2000). Clonal analysis of the Arabidopsis root confirms that position, not lineage, determines cell fate. Planta, 211(2),191-199.

Laux, T. (2003). The Stem Cell Concept in Plants: A Matter of Debate. Cell, 113, 281-283.

Lee, C. \& Clark, S.E. (2015). A WUSCHEL Independent Stem Cell Specification Pathway Is Repressed by PHB, PHV and CNA in Arabidopsis. PLoS ONE, 10(5): e 0126006.

Lin, W. et al. (2019). Mesenchymal Stem Cells and Cancer:Clinical Challenges and Opportunities. Hindawi BioMed Research International, Volume 2019, Article ID 2820853, 12 pages https://doi.org/10.1155/2019/2820853

Lowe, K. et al. (2016). Morphogenic regulators Baby boom and Wuschel improve monocot transformation. Plant Cell, 28,1998-2015.

Machida, Y., Fukaki, H. \& Araki, T. (2013). Plant Meristems and Organogenesis: The New Era of Plant Developmental Research. Plant and Cell Physiology, 54(3),295-301,

Malamy, J.E. \& Benfey, P.N. (1997). Organization and cell differentiation in lateral roots of Arabidopsis thaliana. Development, 124,33-44.

Mayer, K.F.X. et al. (1998). Role of WUSCHEL in Regulating Stem Cell Fate in the Arabidopsis Shoot Meristem. Cell, 95, 805-815.

Meyerowitz EM. (2002). Plants compared to animals: the broadest comparative study of development. Science, 295(5559),1482-1485.

Morrison, S.J. (2001). Stem cell potential: can anything make anything? Curr. Biol, 11, R7-9.

Morus, M. et al. (2014). Plant stem cells as innovation in cosmetics. Acta Pol. Pharm, 71(5), 701707.

Newman, I.V. (1965). Pattern in the meristems of vascular plants. III. Pursuing the patterns where no cell is a permanent cell. J. Linn. Soc. London Bot, 59, 185-214.

Nisa, M.U. et al. (2019). The Plant DNA Damage Response: Signaling Pathways Leading to Growth Inhibition and Putative Role in Response to Stress Conditions. Front. Plant Sci, 10,653.

Orford, K.W. \& Scadden, D.T. (2008). Deconstructing stem cell self-renewal: genetic insights into cell-cycle regulation. Nat Rev Genet, 9(2),115-28.

Richards, B.M. (1955). Deoxyribose nucleic acid values in tumour cells with reference to the stemcell theory of tumour growth. Nature, 175, 259-261

Sablowski, R. (2004). Plant and animal stem cells: conceptually similar, molecularly distinct? Trends Cell Biol, 14(11), 605-11.

Sablowski, R. (2010). Stem cells in plants and animals. Nature Education, 3(9),4

Sachs T. (2005). Pattern Formation in Plant Tissues, Cambridge University Press, 248 p.

Sang, Y.L., Cheng, Z.J. \& Zhang, X.S. (2018). Plant stem cells and de novo organogenesis. New Phytologist, 218, 1334-1339.

Satina, S., Blakeslee, A.F. \& Avery, A. (1940). Demonstration of three germ layers in the shoot apex of Datura by means of induced polyploidy in periclinal chimeras. Am. J. Botany, 27,895-905. 
Scheres, B. et al. (1994). Embryonic origin of the Arabidopsis primary root and root meristem initials. Development, 120, 2475-2487.

Scheres B. (2007). Stem-cell niches: nursery rhymes across kingdoms. Nat Rev Mol Cell Biol, $8(5), 345-354$

Schmid, D. et al. (2008). Plant stem cell extract for longevity of skin and hair. SÖFW J, 134(5), 3035 .

Schnittger, A. et al. (1996). Epidermal fate map of the Arabidopsis shoot meristem. Dev. Biol, 175, $248-255$

Schofield, R. (1978). The relationship between the spleen colony-forming cell and the haemopoietic stem cell. Blood Cells, 4, 7-25.

Schoof, H. et al. (2000). The stem cell population of Arabidopsis shoot meristems in maintained by a regulatory loop between the CLAVATA and WUSCHEL genes. Cell, 100, 635-644.

Schubert, D., et al. (2006). Silencing by plant Polycomb-group genes requires dispersed trimethylation of histone $\mathrm{H} 3$ at lysine 27. EMBO J, 25(19), 4638-49.

Sengupta, S., Jacob K, Moni. \& Sankar, D. (2018). Plant Stem Cells - Regulation and Applications: A Brief Review. Research Journal of Pharmacy and Technology, 11. 1535-1540. 10.5958/0974360X.2018.00286.X.

Spradling, A., Drummond-Barbosa, D. \& Kai, T. (2001). Stem cells find their niche. Nature, 414, 98-104.

Stahl, Y. \& Simon, R. (2005). Plant stem cell niches. Int J Dev Biol, 49,479-489.

Steeves, T.A. \& Sussex, I.M. (1989). Patterns in Plant Development (Cambridge: Cambridge University Press), 388 p.

Stewart, R.N. \& Dermen, H. (1970). Determination of Number and Mitotic Activity of Shoot Apical Initial Cells by Analysis of Mericlinal Chimeras, Amer J Bot, 57(7), 816-826.

Tolbert, R.J. \& Johnson, M.A. (1966). A survey of the vegetative shoot apices in the family Malvaceae. Amer J Bot, 53, 961-970.

Toso, R.D. \& Melandri, F. (2011). Echinacea angustifolia cell culture extract added value for sport and fittness. Nutrafoods, 10(1),19-24.

Trehan, S. et al. (2017). Plant stem cells in cosmetics: current trends and future directions. Future Sci, OA 3(4), FSO226

Van den Berg, C., et al. (1997). Short-range control of cell differentiation in the Arabidopsis root meristem. Nature, 390(6657),287-9.

Wildwater, M., et al. (2005). The RETINOBLASTOMA-RELATED gene regulates stem cell maintenance in Arabidopsis roots. Cell, 123(7),1337-49.

https://slideplayer.com/slide/9414039/01.10.2019'da indirilmiş̧tir.

http://www.cres-t.org/cgi-

bin2/phenotype search2.cgi? $\mathrm{PH}=104 \&$ indivisual=on\&bulk=on\&sort=phenotype22.10.2019'da indirilmiştir. 
International Journal of Scientific and Technological Research

ISSN 2422-8702 (Online), DOI: 10.7176/JSTR/6-02-01

Vol.6, No.2, 2020

https://www.nature.com/stemcells/2009/0903/090312/full/stemcells.2009.39.html 01.03 .2019 $\underline{\text { tarihinde indirilmiștir }}$

www.sciencedaily.com/releases/2009/11/091116165633.htm 01.03.2019 tarihinde indirilmiştir

https://www.researchgate.net/figure/Diagram-of-a-radial-longitudinal-section-through-root-apicalmeristem-RAM-showing-the_fig3 475566060 1.03.2019 tarihinde indirilmiștir

https://www.easybiologyclass.com/difference-between-primary-and-secondarymeristem/01.03.2019 tarihinde indirilmiștir

http://www.vytrus.com/,01.01.2014 tarihinde indirilmiștir

https://www.ncbi.nlm.nih.gov/pmc/articles/PMC5674215/pdf/fsoa-03-226.pdf01.03.2019tarihinde indirilmiștir

www.ctkcosmetics.com 01.01.2014 tarihinde indirilmiștir 